\title{
Amacrine Cell
}

National Cancer Institute

\section{Source}

National Cancer Institute. Amacrine Cell. NCI Thesaurus. Code C12626.

A retinal neuron that lacks large axons, having only processes that resemble dendrites. 